\title{
South African Mandatory Offers Regime: Assessing Minorities' Leverage to Seek Recourse and Equal Treatment in Takeover Bids
}

\author{
Paul Nkoane*
}

\section{Abstract}

A firm intention announcement must be made when the offeror is able and willing to acquire securities, and when a mandatory offer must be made. When the firm intention announcement is implemented, some sort of a contract is created. This rule has helped to determine the particular time the offeror should be liable to minorities. The question of when the offeror should bear the obligation to implement mandatory offers in aborted takeovers is thus no more problematic. Previously, the courts wrestled with this issue, but delivered what appears to be unsatisfactory decisions. This article will discuss the effect of a firm intention announcement and the responsibility that attends the making of that announcement. It intends to illustrate the extent of liability the offeror must bear in the event of a lapsed takeover, before and after the making of the firm intention announcement. The article examines the manner in which takeover rules can be enforced, and whether the current measures afford minorities proper protection. This brings to light the issue of equal treatment in takeovers and the fallacy thereof. A minor appraisal of the takeover rules in two jurisdictions in Europe (the United Kingdom and the Netherlands) is conducted to assess how equal treatment for minorities is promoted. Due to the difficulty minorities may experience in enforcing equal treatment in company takeovers, the article advocates for the alteration of the current South African takeover procedure for the promotion of minorities' interests and for establishing rules that provide the offeror adequate information.

Keywords: company takeovers, mandatory offers, minority shareholders, equal treatment, acquisition procedure

\section{Introduction}

Under South African law, a mandatory offer must be implemented when an offeror obtains a beneficial interest equal to or above the prescribed percentage in

Paul Nkoane is lecturer at the College of Law of the University of South Africa in Pretoria. any voting securities of a regulated company. ${ }^{1}$ The obtained beneficial interest must be at least $35 \%$ or more of the voting securities. Such acquisition of securities must result in an affected transaction. ${ }^{2}$ This kind of affected transaction compels the offeror to make an offer for minority securities on the same terms as the obtained securities or soon to be obtained securities. ${ }^{3}$ Thus, the offeror must follow procedures that lead to compliance with the takeover rules; these procedures are meant to support the regime of mandatory offers, particularly to ensure equal treatment of all security holders. The procedures inherently encourage devotion to the rules that shield affected security holders in takeover bids. 4

In practising general caution when acquiring securities, the offeror must ensure that the information it proposes to disclose is correct and reliable. ${ }^{5}$ To secure the credibility of the marketplace, ${ }^{6}$ the fundamental transactions and takeover regulations comprise announcement rules that guarantee the preservation of delicate information. ${ }^{7}$ Consequently, when a mandatory offer has to be made to minorities, the offeror must make a firm intention announcement. ${ }^{8}$ An offer, which must be made before the firm intention announcement, cannot be retracted after the announcement, even before acceptance of the

1. Section 118(1) of the Companies Act 71 of 2008: (a) a public company; a state-owned company, except to the extent that any such company has been exempt; and specific private companies. Further see rule 81 (o) of the Companies Regulations of 2011.

2. Section 117(1)(c) of the Companies Act 71 of 2008: (i) a transaction or series of transactions amounting to the disposal of all or the greater part of the assets or undertaking of a regulated company; (ii) an amalgamation or merger involving at least one regulated company; (iii) a scheme of arrangement between a regulated company and its shareholders; (iv) transactions in terms of Section 122, see note 30; (v) the announced intention to acquire a beneficial interest in the remaining voting securities of a regulated company not already held by a person or persons acting in concert; (vi) a mandatory offer and (vii) compulsory acquisition.

3. Rule 111(3) of the Companies Act 71 of 2008: Section 123(3)(b) and Companies Regulations of 2011.

4. See Section 127 of the Companies Act 71 of 2008 and rule 98 of the Companies Regulations of 2011: where certain omission or breach of the takeover protocol will result in a prohibited dealing.

See rule 111(8) of the Companies Regulations of 2011.

6. Section 119(1)(a); (b) and (c) of the Companies Act 71 of 2008 Rule 100 and rule 101 of the Companies Regulations of 2011. Rule 101(1) of the Companies Regulations of 2011. 
offer. Therefore, the offeror is statutorily bound to perform when called upon to do so, or else, a legal suit may ensue. ${ }^{9}$

It appears that a firm intention announcement creates some genus of a contract among the offerors and offerees. ${ }^{10}$ This, of course, is an imperfect contract, as its perfection hinges on acceptance of the offer. It stands to reason that a quasi-contract ${ }^{11}$ is formed between the offeror and the offerees when a firm intention announcement is made. ${ }^{12}$ When a firm intention announcement is made, the offerees are thereupon granted the right to recourse if the offeror fails to follow takeover rules.

Despite the implementation of a firm intention announcement, the proposed takeover may not materialise. ${ }^{13}$ Upon breach of takeover rules, it must be determined who should carry the liability for the ensuing losses. If the offeror is culpable, the offeror should endure the burden of compensating the affected security holders for the damage it has caused. ${ }^{14}$ Conversely, who should bear liability where the offeree is liable for a failed bid? For instance, when the offeree fails to adhere to the terms of the agreement at an advanced stage of the acquisition. Where the offeror withdraws from the negotiations before a firm intention announcement is made, the situation is not problematic, as contractual liability does not arise. ${ }^{15}$ The problem occurs where the firm intention announcement has been made. This article will illustrate that a firm intention announcement qualifies minorities to seek recourse for the damage suffered. Through implementing a firm intention announcement, the offeror agrees to contract with the offerees, provided all the requirements of the offer are met. The requirements, however, must not be based on a subjective condition that limit the making of a mandatory offer. ${ }^{16}$ This quasi-contract binds the offeror even before the offerees accept the offer. ${ }^{17}$

The article intends to probe this regime of takeovers mainly to limit possible confusion with respect to the liability that must flow in aborted takeovers; it fathoms the extent of liability the offeror should assume upon breach of the takeover rules and tests the theory of equal treatment in takeovers. It intends to illustrate that the value of offers should be clearer in takeovers bids and

9. This position was adopted to address the difficulties encountered in the Haslam v. Sefalana Employee Benefits Organisation [1997] 4 All SA 269 (W) case.

10. Rule 94, rule 101(3) and rule 101 (7) of the Companies Regulations of 2011: Negotiations referred to in the regulations implies to contractual negotiation, and similarly offer means contractual offer to purchase securities.

11. The author uses the word quasi-contract to illustrate that there is no full contract but a contract that binds one party only (the offeror), in cases where the other party (the offeree) would have accepted the offer.

12. Rule 101(1) and (2) of the Companies Regulations of 2011

13. Rule 111(5) of the Companies Regulations of 2011.

14. Benson v. SA Mutual Life Assurance Society 1986 (1) SA 776 (A)

15. Rule 94(2) of the Companies Regulations of 2011.

16. The offeror may thus set a condition on the expiry of the offer or the minimum number of securities required in offer; see rule 81 (d) and rule $101(7)(v)$ and (viii) of the Companies Regulations of 2011.

17. Rule 96 and rule 101(2) of the Companies Regulations of 2011. that offers must be submitted concurrently to all security holders to ensure equal treatment. Moreover, a synopsis of the takeover regimes in the Netherlands and the United Kingdom is provided to determine whether the rules that promote equal treatment during takeover bids in these jurisdictions deliver adequate protection to minorities.

\section{Mandatory Offers}

It is judicious to first probe the rules contained in the mandatory offer regime. The mandatory offer rules have developed over the years. ${ }^{18}$ Even so, most of the takeover rules contained in Securities Regulation Code on Takeovers and Mergers (the Code), and which triggered mandatory offers, still apply today. Thus, a mandatory offer has to be made where the offeror/s acting alone or in concert ${ }^{19}$ acquire securities of a regulated company equalling or above the prescribed percentage. ${ }^{20}$ In essence, the offeror/s have to gain a beneficial interest equal to or above the prescribed percentage (resulting in an affected transaction) before the offeror/s could be bound to make offers for minority securities. ${ }^{21} \mathrm{~A}$ mandatory offer is triggered by the transfer of the prescribed percentage (or rather the control) from the offeree/s to the offeror/s in an affected transaction. ${ }^{22}$ The word control is not included in the takeover rules under Companies Act 71, but it still has a significant bearing on when a mandatory offer should be made. ${ }^{23}$ The gaining of control should lead to all relevant security holders receiving equal treatment. The mandatory offer rule is particularly intended to ensure fair and equal treatment of all holders of relevant securities when the transference of company control is in the offing. ${ }^{24}$ It is submitted that minorities could be treated unfairly during takeovers, and ill treatment can last well past the takeover period. ${ }^{25}$

It is explicit that this takeover regime is intended to shield minority security holders, of companies that are

18. Contrast Chapter XVA of the Companies Act 61 of 1973, Securities Regulation Code on Takeovers and Mergers with Section 123 of the Companies Act 71 of 2008 and chap 5 of the Companies Regulations of 2011. Whereas, this regime of takeovers has transformed from the Securities Regulation Code on Takeovers and Mergers (the Code) format, in general the regime only experienced minor alterations.

19. See Section 117(1)(b) of the Companies Act 71 of 2008.

20. Section 123 of the Companies Act 71 of 2008 and F.H.I. Cassim (ed.), Contemporary Company Law, 2nd ed., Cape Town: Juta (2012) Section 15.5.9.

21. Companies Regulations of 2011: rule 96.

22. See P. Nkoane, 'Is There a Need for Mandatory Offers in Company Takeover: A Critical Analysis?', 36 Obiter 363, at 366-70 (2015).

23. Ibid., at 367-9. While it was a careful decision to jettison the theory of control from the ambit of mandatory offers in the Companies Act 71, the term control appears to still underpin this regime. A proper reading of the Companies Regulations will confirm that the triggering of a mandatory offer hinges on the change of control of the company.

24. See explanatory notes 1 (a) and rule 8.1 of Securities Regulation Code on Takeovers and Mergers (the Code).

25. Spinnaker Investments (Pty) Ltd v. Tongaat Group Ltd 1982 (1) SA 65 (A), at 72-3. 
destined for a change of control, against abuse and facilson or persons who acquire securities in the range of the prescribed percentage may potentially gain control of the target company. In brief, the mandatory offer regime is associated with the theory of ostensible control, which is founded on the idea that a shareholder can control the outcome of a company's resolutions with the ownership of only $35 \%$ of the company's securities. ${ }^{26}$ This can occur where the company's shareholding is widespread.

Regarding acute cases, it is submitted that the mandatory offers rule serves the purpose of dispiriting the so-called corporate looters (generally referred to as predator, white-collar looter or early-dawn raider) by forcing them to abandon the booty. ${ }^{27}$ This is accomplished through rules that impose a submission of a similar offer for all similar securities. ${ }^{28}$ This allows all affected security holders to stake a claim in the premium accordingly empowering affected security holders of a company where control has changed to exit the company at the best price possible. ${ }^{29}$

The South African mandatory offers regime is formulated on experience and the need to protect minority shareholders. In this respect, the article undertakes an analysis of the regimes in the Netherlands and the United Kingdom to determine whether minorities are adequately protected during takeovers and the these jurisdictions.

\section{The European Directive on Mandatory Offers and the Netherlands Regime}

The European Union (EU) has continually endeavoured to bring uniformity in company takeovers across its different Member States through provision of minimum guidelines on the conduct and transparency of takeover bids. ${ }^{30}$ To this end, the EU formulated the Takeover Directive (2004/25/EC) to harmonise the takeover laws of different Member States. The Directive does not itate equal treatment in takeovers. It is held that a perpaid for securities acquired or soon to be acquired, degree of the equal treatment afforded to minorities in

promote rigid rules, thus affording Members States the flexibility to adopt their own measures that comply with the minimum requirements of the Directive. ${ }^{31}$ Before the implementation of the Takeover Directive by the EU Member States, the rules related to the conduct of takeover offers were quite diverse throughout the EU. Thus, takeovers could not be commenced with the same expectation of success in different Member States, and shareholders did not have the same protection and opportunities. ${ }^{32}$ The purpose of having uniform laws across different Member States of the EU has filtered down to takeover laws, including mandatory offer rules. In the event a person, as a result of his own acquisition or the acquisition by persons acting in concert with him, reaches a certain percentage of the voting rights in a company which gives him control of that company, the EU Member State must ensure that such a person is required to make a mandatory offer in order to protect the minority shareholders of that company. ${ }^{33}$

As mentioned, the rules are flexible and afford Member States the discretion to determine what constitutes the gaining of control. The Directive also allows the national law that provides for adequate protection of the minority shareholders to create derogations from the mandatory offer rule. ${ }^{34}$ This has permitted Member States to create rules that do not lead to the making of a mandatory offer in all takeover offers, particularly if the acquisition does not pose a threat to minorities. ${ }^{35}$ However, as a rule under the Directive that allows no divergence, where a mandatory offer must be made, the offeror must be prepared to acquire all voting securities of the target company. ${ }^{36}$ This generally increases the cost of acquisitions, both friendly and hostile, to a level that acts as a deterrent to takeover bids altogether. ${ }^{37}$ This sweeping rule justifies the inclusion of the derogation rule in the EU Directive to moderate deterrence that could stem from the enforcement of the mandatory offer rules, particularly where the gaining of influential control is not possible or where offers for company securities would not lead to the practice of unfair treatment.

Similar to what constitutes control, the Member States can discretionarily formulate their announcement rules. The announcement rules appear to be hinged on the need to ensure transparency and integrity of the market

31. T. Papadopoulos, 'The Mandatory Provisions of the EU Takeover Bid Directive and Their Deficiencies', 6 Law and Financial Markets Review 525 (2007).

32. C. Cascante and J. Tyrolt, European Directive Takeover Guide, https:// www.ibanet.org/Document/Default.aspx?DocumentUid=D999E949ED7C-44AE-86B1-2F2E8A36C069 (last visited 28 September 20202).

33. Ibid

27. Haslam v. Sefalana Employee Benefits Organisation [1997] 4 All SA 269 (W), 278.

28. See W.D. Andrews, 'The Stockholders Right of Equal Opportunity in the Sale of Shares', 78 Harvard Law Review 505, at 515 (1964); for the need to treat every shareholder equally.

29. E. Armson, 'Models for Takeover Dispute Resolution: Australia and the UK', 5 Journal of Corporate Law Studies 401, at 412-14 (2005).

30. B. Clarke, 'European Takeover Regulation-The Latest Draft of the 13th Company Law Directive', 11 European Business Law Review 482 (1999).

34. Article 3, Paragraph 2 of the EU Directive on Takeovers.

35. L. Enriques, 'The Mandatory Bid Rule in the Takeover Directive: Harmonization Without Foundation?', 4 European Company and Financial Law Review 440, at 443 (2004).

36. C. Clerc, F. Demarigny, D. Valiante \& M. de Manuel Aramendía, A Legal and Economic Assessment of European Takeover Regulation (2012), at 53

37. Ibid 
of the offeree securities during takeovers. ${ }^{38}$ It then stands to reason that any announcement protocol must lead to a transparent market and the protection of the value of the target company's securities. This should also include minority interests. Nevertheless, the EU Directive does not overtly advocate for the liability that should ensue after the announcement for takeovers has been made, particularly measures that empower minorities to seek compensation. This obligation is consigned to national lawmakers of the different Member States. Different Member States may opt for different announcement rules, some States may adopt announcement rules that exert an obligation on the offeror. The Member States may equally formulate the degree of liability that should stem from the breach of the takeover rules. Whether this should be an adequate formula that affords the minorities equal treatment in company takeovers leads to a debate.

\subsection{Mandatory Offers in the Netherlands}

Historically, legal commentary on takeover laws has not been in short supply in the Netherlands. ${ }^{39}$ The Netherlands, just like many other jurisdictions, has experienced a progression in its takeover laws, from centralised domestic laws to the adoption of laws that are in harmony with similar regional laws. The Netherlands, as part of the EU, adopted the EU Directive to harmonise its takeover laws, ${ }^{40}$ of course, with the retention of some distinctiveness. The Netherlands' regime contains some rules that are identical to the rules of South Africa and the United Kingdom; however, there are also noticeable divergences. This article seeks to evaluate the protection afforded to minorities during takeover bids, particularly when a mandatory offer must be made, and the machinery minority security holders may invoke to enforce equal treatment. It assesses the contractual implications of the gaining of control of a regulated company and the rules that are aimed at protecting security holders.

The gaining of controlling influence triggers a mandatory offer rule in the Dutch law. The controlling influence is considered to have occurred when the offeror is able to exercise $30 \%$ or more of the voting rights in the general meeting of shareholders of a regulated company. ${ }^{41}$ This includes offerors that are acting in concert

38. D. Van Gerven, 'Rules of Community Law Applicable to Takeover Bids', in D. Van Gerven (ed.), Common Legal Framework for Takeover Bids in Europe, Vol. 1 (2008) 1, at 26.

39. B.J.H. Crans, 'Netherlands', 19 International Business \& Law 262 (1991); C. Vellekoop, 'Hostile Takeovers in the Netherlands', 7 International Financial Law Review 11 (1988); C. Huiskes, ‘Dutch Proposal to Restrict Anti-Takeover Devices', 17 International Financial Law Review 29 (1998); J.D. Kleyn, 'Keeping Control in the Netherlands', 9 International Financial Law Review 10 (1990) and D. Quinn, 'Dutch Treat: Netherlands Judiciary only Goes Halfway towards Adopting Delaware Trilogy in Takeover Context', 41 Vanderbilt Journal of Transnational Law 1211 (2008).

40. J. Cremers and R. H. van Het Kaar, 'Implementation of the Takeover Bids Directive in the Netherlands' in J. Cremers, and S. Vitols (Eds) Takeovers With or Without Worker Voice: Workers' Rights Under the EU Takeover Bids Directive (2016) 181-93.

41. P. Corten (ed), Public Takeover Bids in the Benelux. Loyens \& Loeff (2011), at 69 with each other. ${ }^{42}$ Those acting in concert or acting alone must observe takeover rules; they must exercise general caution when tendering to acquire control of the target company. Any price-sensitive information must be kept confidential during the takeover process; however, if such information is leaked, an advisory announcement should immediately be made to protect the value of the offeree securities. Failure to make the announcement may culminate in administrative sanctions or shareholders instituting claims for damages against the target company and/or the offeror. ${ }^{43}$ This rule limits reckless conduct and provides security holders clear remedies during takeovers.

A compulsory announcement must be made when the offeror and the board of the offeree company have reached an agreement or a 'conditional agreement' about an offer. ${ }^{44}$ The making of an offer to acquire regulated securities in the Netherlands system differs from those in the South African and the British systems. The making of an offer for company securities, unlike in the South African system, does not in itself create a contract, quasi or not. However, to discourage uncontrolled conduct during the bidding process, there is a 'put up or shut up' rule that the target company may invoke to impose disclosure obligations on a potential offeror if the offeror has publicly announced its intention to acquire securities. ${ }^{45}$ This rule should be seen as a machinery to protect the target company's securities from possible market flux. ${ }^{46}$ Once the announcement to acquire securities that trigger a mandatory offer rule has been made, the offeror may not simply withdraw its offer. ${ }^{47}$ This rule serves the same purpose as the South African firm intention announcement rule. The difference is that the offeror may only make the announcement when the conditional agreement has been reached regarding the offer and acceptance, and the possible cost involved. ${ }^{48}$ In South African jurisprudence, the offer to acquire securities must not be founded on subjective conditions. ${ }^{49}$ The use of the word conditional in the Dutch law leads to the impression that the whole agreement is hinged on a circumstance. This is so, because in practice, most bids are made conditional subject to approval by the Dutch Financial Markets Authority. It is quite clear that the word condition may relate to the acceptance of the offer or any other condition that may relate to the offer. This is more acute when the offeror disputes the obligation to make a mandatory offer. In this respect, one wonders whether the announcement could be regarded as advantageous to minorities due to the whole agreement being subject to the approval of the relevant authority.

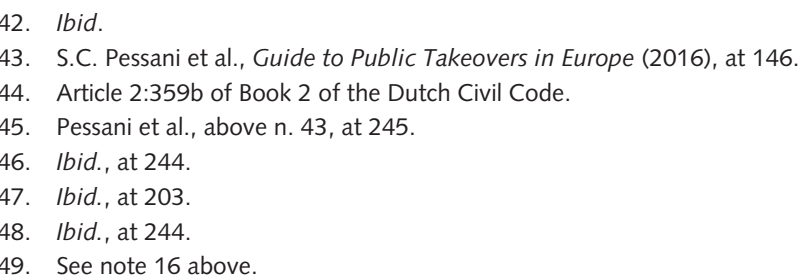


When interpreted accurately, the 'put up or shut up' rule is not framed to necessarily focus on or encompass mandatory offers. The minorities are always on the outside, looking in, particularly when a mandatory offer is a secondary offer. Distinct to the South African firm intention announcement rule, the 'put up or shut up' rule does not create an obligation on the offeror towards minorities. Upon the offeror failing to make a mandatory offer, the minorities may only enforce the same through filing a request with the Enterprise Chamber as the Dutch Financial Markets Authority lacks authority to enforce mandatory offers. ${ }^{50}$ Remedies that are available to minorities largely affect the offeror's rights to and interests in the acquired securities, and do not provide minorities contractual rights. The Enterprise Chamber may take steps, at the minorities' request, which may include suspending the voting rights of the prospective offeror in the target company, ordering the decrease of its shareholding or suspending or nullifying any resolutions that may have been adopted during the general meeting of shareholders after the duty to make a mandatory bid arose. ${ }^{51}$

It is overt that the regime lacks clear machinery that functions to elucidate the liability of the offeror towards minorities when a mandatory offer is disputed, thus simply relegating minorities to the marginal limits of equal treatment. The minorities, on their own accord, should organise and launch a legal challenge with the Enterprise Chamber if they are unfairly treated. Whether this regime promotes equal treatment of all shareholders in takeovers is an issue that is quite moot, but conventional wisdom has it that there is inequality in the practice of equal treatment.

\section{The United Kingdom's Mandatory Offer Procedure}

In the United Kingdom, supervision of the trading of companies' securities has long been considered a necessity in controlling the conduct of security traders. This is similarly essential in the context of one of the more public fields of market activity - the corporate takeover or merger. ${ }^{52}$ The City Code on Takeovers and Mergers (the Code) is formulated to administer company takeovers and mergers. Initially, the Code was a mere directory and not an enforceable law. ${ }^{53}$ The Code has since been turned into a binding law. ${ }^{54}$ The Code is designed mainly to ensure that shareholders in an offeree company are treated fairly and are not denied an opportunity

50. Pessani et al., above n. 43 , at 35

51. Pessani et al., above n. 43 , at 35 .

52. B.J. Davies, 'An Affair of the City: A Case Study in the Regulation of Take-overs and Mergers', 36 Modern Law Review 457 (1973).

53. T. Shea, 'Regulation of Takeovers in the United Kingdom', 16 Brooklyn Journal of International Law 89, at 90 (1990).

54. Section 10 (d) of The City Code on Takeovers and Mergers (2016) (the Code). to decide on the merit of a takeover bid. ${ }^{55}$ In this respect, shareholders in the offeree company of the same class must be afforded the same treatment by the offeror/s. ${ }^{56}$ The Code is developed to reflect the appropriate business standards and how fairness to offeree company shareholders can be achieved. ${ }^{57}$ The mandatory offers regime was created to promote equality and to protect minorities in takeovers. When any person acquires an interest in shares that carry 30 percentage or more of the voting rights of a company, a mandatory offer must be extended to minorities. Similarly, any person, together with persons acting in concert with him, who is interested in shares which taken together carry not less than $30 \%$ of the voting rights of a company, but no more than $50 \%$ of the voting rights, must make mandatory offers to minorities. ${ }^{58}$

In all regulated security purchases, the offeror/s must approach the board of the offeree company first. After the offeror has approached the board for the purpose of acquiring securities, the rules command that an announcement must be made when a firm intention to make an offer is reported to the board by the offeror or on behalf of an offeror, irrespective of the attitude of the board to the offer. ${ }^{59}$ Similarly, an announcement must be made immediately upon acquisition of any interest in shares that gives rise to an obligation to make mandatory offers. ${ }^{60}$ An offeror (or its advisers) must report a firm intention to make an offer in the first instance to the board of the offeree company (or its advisers). Subsequent to having been approached, the offeree company is responsible for making any announcement required under the mandatory offers rule. ${ }^{61}$ Similarly, the Panel must be consulted in advance, prior to the announcement of a firm intention to make an offer. ${ }^{62}$ Offers can also be made under the condition that the statements pronounced, mainly regarding the price of a possible offer and the terms of the offer, do not bind the offeror. ${ }^{63}$ Owing to this provision, one wonders whether the announcement should be regarded as a firm intention to acquire securities.

Even after the offeror commits to acquire securities, the offeror is permitted to withdraw its offer. ${ }^{64}$ This allows the offeror the scope to analyse and decide whether to continue or abandon the acquisition of securities if a mandatory offer is triggered. This is more relevant after the offeror becomes aware of the number of shares that would be issued. ${ }^{65}$ The offeror can then decide to continue with or withdraw the offer. The offeror would

55. F. Ipekel, 'Operation of the Equality Principle in the UK City Code on Takeovers and Mergers', Yearbook of International Financial and Economic Law 425 (2000-2001).

56. Section 2(a) of the Code.

57. Ibid

58. Ibid

59. Rule 2.2 (a) of the Code.

60. Rule 2.2 (b) of the Code

61. Rule 2.3 (c) of the Code.

62. Rule 2.5 (a) of the Code

63. Rule 2.5 (a)(i) and (ii) of the Code.

64. Rule 2.10 (c) of the Code.

65. Rule 2.9 of the Code. 
proceed to acquire securities with full knowledge of the number of securities that are tendered for sale and the costs involved. Thus, mandatory offers may not represent a surprise transaction to the offeror, and if the cost of a mandatory offer is beyond the offeror, the offeror may not proceed with the offer. In contrast to the South African regime, the firm intention announcement in the United Kingdom does not bind the offeror to an unconditional commitment to the offerees. ${ }^{66}$

The withdrawal of an offer after the publication of the firm intention to purchase could lead to a possible market flux. The withdrawal may (may not) stem from the pressure to make a mandatory offer. This then raises the question of whether takeovers afford minorities equal treatment. The value of the securities of the affected company could be adversely affected by the news that the investors have abandoned a bid to takeover a company. Speculation may further fuel the flux. Ensuing speculations could lead to the share price of the company falling. The South African takeover regime is constructed to prevent this sort of reaction, and if this sort of drop could not be avoided, the offeror should bear liability for any damage caused by its termination of the offer after a firm intention announcement has been published. This is the premise of the firm intention announcement ideology in the South African regime. The firm intention announcement regime in South Africa also affords minorities the right to approach the courts for recourse for breach of contract as if they have contracted with the offeror.

Under the United Kingdom's law, failure to make or fulfil a mandatory offer does not render the initial transaction void or unenforceable or affect its validity. ${ }^{67}$ The minority security holders may approach the Panel if the offeror fails to make a mandatory offer; in turn, the Panel may approach the court to have the offeror comply with the mandatory offers rule. ${ }^{68}$ The court may make a ruling it considers to be just, including awarding damages or ordering that the offeror procure the minority securities. ${ }^{69}$ It is clear that the awarding of damages does not equate to equal treatment in the true meaning of the word, even though the court could regard it as a fitting remedy. Thus, when majority securities are acquired at a premium and the minorities are awarded damages in the form of the paid premium, equal treatment does not occur.

\section{The Impact of the Firm Intention Announcement in South African Law}

Due to the necessity to promote stable markets and the fulfilment of takeover regulations, procedures must be observed when offers are made in respect of securities of regulated companies. The law, therefore, compels offerors to follow takeover protocol when tendering to procure securities of a regulated company, in cases where the transaction amounts to an affected transaction. ${ }^{70}$ The consequence that flows from the making of the firm intention announcement is distant to the rules of contract law, and it poses obvious difficulties to fully comprehend. The author's opinions on the consequence of the firm intention announcement are hinged on the interpretation of the wording of rules 101 (1)-(4) of the Companies Regulations of 2011. The firm intention announcement contains an official written offer to purchase securities. This written offer must be submitted to the independent board, which in turn must refer it to the offerees through a solicitation campaign. This means that through publishing the firm intention announcement, the offeree company would have considered the offeror as binding itself to acquire the offerees' securities. The offeree company board would partially accept the offer on behalf of the offerees to bind the offeror when it publishes the firm intention announcement, but the offer would still be subject to the offerees' approval. Thereupon, the offeror cannot withdraw its offer without the consent of the offeree company. Hence, it is emphasised that the offeror must proceed with the offer after a firm intention announcement is made - the offeror is afforded no discretion to act otherwise. Since the offeree company accepts the offer on statutory grounds to bind the offeror, the offeree cannot be sued for breach of contract if it later rejects the offer. Even in cases where the offeror is sanctioned to make a firm intention announcement because the independent board has failed to do so, the same consequences would still follow. Where the mandatory offer should be made after the initial acquisition, the making of a firm intention announcement qualifies minorities to enforce specific performance as if they contracted with the offeror. This position was adopted to address the difficulties encountered in the Haslam v. Sefalana Employee Benefits Organisation $^{71}$ case, discussed later in this article.

The offeror has to approach the board of an offeree company when proposing to acquire securities of a regulated company. ${ }^{72}$ Where the board of an offeree regulated company is approached with a view to acquire securities, the board may require reasonable evidence that the offeror is, or will be, in a position to implement 
the offer in full. ${ }^{73}$ Where the offer involves price-sensitive information, a cautionary announcement must be made. ${ }^{74}$ There is another declaration that is similarly central in ensuring that takeover regulations are properly observed. The making of a firm intention announcement is basic when the transaction triggers a mandatory offer. ${ }^{75}$ The responsibility of implementing a firm intention announcement rests with the independent board of the offeree regulated company, and if the independent board of an offeree fails to make the announcement, the Panel may sanction the offeror to make the announcement. ${ }^{76}$ It is correct to assume that the announcement protocols serve a fundamental function in takeovers. Accordingly, it is prudent to probe how the announcements affect the takeover rules.

\subsection{A Case Law Appraisal of the Obligation to Extend Offers to Minorities}

The author intends to tread back to the time when the announcement regime was not central in takeovers. The Panel did not necessarily interfere in takeovers when announcements were not made. Lack of clarity on when an offeror should bear the obligation to compensate minorities in failed takeovers caused much trouble. The courts were at variance on this matter. ${ }^{77}$

The court in Haslam v. Sefalana Employee Benefits Organisation $^{78}$ had to determine whether the offeror who repudiated the contract to acquire securities in a terminated affected transaction was liable to minorities for specific performance, even when the offeror did not make an offer to minorities. The court sought to determine whether the offeror was legally bound to minorities by assessing what the terms 'acquisition' and 'securities' entailed in takeovers. The court first pointed out that the Code mainly sought to secure adherence to takeover rules by requiring offerors to engage in negotiations only if they can completely follow the takeover rules. In this regard, the courts referred to Section 440L and $440 \mathrm{M}(4)$ of the Companies Act 61 of 1973, which, inter alia, stated that

no person shall enter into or propose an affected transaction except in accordance with the Code, [and] any person who contravenes any of the rules shall be liable to any other person for any loss or damage suffered by that person as a result of such contravention. $^{79}$
The court further stated that in interpreting the definition of 'acquisition' and of 'securities', consideration must be given to the Code's purport and spirit. ${ }^{80}$ The Code's formulation and application are directed 'principally to ensure fair and equal treatment of all holders of relevant securities in relation to affected transactions' ${ }^{81}$ The general principle 1 of the Code emphasises this fact in the following words: 'all holders of the same class of securities of an offeree company shall be treated similarly by an offeror' when acquiring securities of a regulated company. ${ }^{82}$ The court averred that the word 'acquire', when construed widely, denoted/s the right to attain ownership of 'securities'. Accordingly, by mere intention to acquire ownership of securities in a regulated company and concluding a contract to that effect, the offeror assents to acquire minority securities. ${ }^{83}$

The court, further, held that a concluded contract which is terminated qualifies minorities to seek recourse if the terminated transaction constituted an affected transaction. Therefore, minorities are entitled to seek an order of specific performance or damages for compensation. This decision found affluent buttress in the academic circle - it was argued that the decision was accurate. $^{84}$

The matter was referred to the Supreme Court of Appeal. ${ }^{85}$ The court adopted a different view. It held that ' $[\mathrm{w}]$ hat requires to be appreciated at the outset, is that shareholders are not ordinarily entitled to equality of treatment when offers to purchase their shares are made'. ${ }^{86}$ It continued, 'The sole rationale for the existence of an obligation to make a similar offer to other shareholders, namely, a transference of control, has fallen away prior to the making of an offer to them and there no longer exists any present prospect of the offeror acquiring control'. ${ }^{87}$ The court held that '[a]n offeror who has not completely acquired securities of a company would obviously not be entitled to vote as if he, she or it were a registered shareholder' ${ }^{88}$ It concluded that 'it is of course so that there appears cursorily to be inequality of treatment but the respective positions of the litigants virtually remained the same'. ${ }^{89}$ If an offeror has contracted unconditionally to purchase shares from a shareholder, repudiation of the agreement may well entitle the offeree to damages. ${ }^{90}$ However, a shareholder to whom no offer has been extended, let alone accepted,
73. Rule 99(3) of the Companies Regulation 2011.

74. Rule 100 of the Companies Regulation 2011.

75. Rule 101(1) of the Companies Regulation 2011.

76. Rule 101(4) of the Companies Regulation 2011.

77. Some may erroneously argue that Haslam v. Sefalana Employee Benefits Organisation [1997] 4 All SA 269 (W) and the appeal case of Sefalana Employee Benefits Organisation v. Haslam 2000 (2) SA 415 (SCA) are obsolete. The author suggests that, as far as the issue of aborted takeovers is concerned, these cases still provide an indispensable illustration of the difficulty associated with aborted takeovers.

78. [1997] 4 All SA 269 (W).

79. Haslam v. Sefalana Employee Benefits Organisation [1997] 4 All SA $269(\mathrm{~W})$, at 273.
80. Ibid., at 274

81. Ibid., at 274

82. Ibid., at 274

83. Ibid., at 276-7.

84. See M.P. Larkin and J. Boltar, 'Company Law (Including Close-Corporation)', Annual Survey of South African Law 403, at 415-16 (1997) and S. Luiz, 'Mandatory offers', 12 South African Mercantile Law Journal 382, at 385-8 (2000).

85. See Sefalana Employee Benefits Organisation v. Haslam 2000 (2) SA 415 (SCA).

86. Ibid., Para. 4.

87. Ibid., Para. 7

88. Ibid., Para. 15.

89. Ibid., Para. 10.

90. Ibid., Para. 10. 
and with whom there is, therefore, no contractual relation, is in a very different position. ${ }^{91}$

It appears that if control has not been transferred, minorities cannot jump onto the litigation bandwagon with the sole purpose of seeking compensation for unforeseeable damages. To aver that minorities should be entitled to an order of specific performance under such circumstances is at best fatalistic and at worst illusory. ${ }^{92}$

The court, thus, rejected the notion that minorities were entitled to recourse in aborted takeovers even though the majority may institute a claim for damages, therefore, upholding the appeal. The court held that the whole rationale for the implementation of the mandatory offer regime is to afford minorities protection when control of the targeted company has changed. The judgment, somewhat, sought to draw a clear line between attempted acquisition and completed acquisition vis-à-vis the duty to make mandatory offers. Even though the court premised its decision on contract law, the decision has not steered clear of criticism. ${ }^{93}$

\subsection{How Has a Firm Intention Announcement Protocol Enhanced the Law?}

The author in this section intends to evaluate how the current rules affected the aforementioned position and to analyse the extent of damages an offeror must bear in failed acquisitions. It must be averred that rule 4.2.4 of the Code affected aborted acquisitions in that it advanced the implementation of the cautionary and firm intention announcements. As already specified, the author does not intend to extract much currency from the law archives regarding transformation of the takeover rules. The author mainly seeks to deal with the prevailing takeover rules.

The author shall first bring into focus the consequences of the breach of cautionary announcement in terms of the takeover rules and the possible legal recourse arising therefrom. The mentioning of this rule is important because the cautionary announcement forms an integral part of takeovers and, in some cases, precedes a firm intention announcement. There is no specific time that a cautionary announcement should be made, but if the need arises, it should be made when there is suspicion that sensitive information could be leaked. The making of the cautionary announcement depends on the nature of the securities and their volatility to certain information. ${ }^{94}$ Immediately after the parties (offeror or offeree) gain knowledge of any price-sensitive information and the necessary degree of confidentiality of such

91. Ibid., Para. 10.

92. Ibid., Para. 11.

93. See S. Luiz, 'Mandatory offers', 12 South African Mercantile Law Journal 382, at 388-93 (2000): according to Luiz the court should have narrowed the matter to whether an acquisition of securities transpired. This approach, it is argued, would provide certainty for the market and provides the minority shareholders the right to legal recourse. Thus, Luiz believes the making of a mandatory offer is not premised on the theory of change of company control.

94. See Section 3.4 of the Johannesburg Stock Exchange (JSE) Listings Requirements. information cannot be maintained, or if the company offeree suspects that confidentiality has or may have been breached, the offeree company must publish a cautionary announcement. ${ }^{95}$ The announcement is aimed at warning the parties involved in a takeover to exercise caution when dealing with securities or sensitive information and to pronounce that the offeree company is subject to a takeover bid. ${ }^{96}$ Although the making of a cautionary announcement does not necessarily result in a contractual bond between the offeror and the offeree, ${ }^{97}$ it serves the purpose of protecting security holders through abating the depreciation of the offeree company's securities. The cautionary announcement aids in ensuring that price-sensitive information is not carelessly leaked to the market, ${ }^{98}$ and if there is a leak, the announcement is intended to cushion the effect of the leak. ${ }^{99}$ The obligation to ensure that price-sensitive information is treated with caution rests with both the offeror and the offerees; failure to practice due care could result in the guilty party being liable for delictual damages. ${ }^{100}$

Conversely, the making of a firm intentions announcement leads to contractual liability. ${ }^{101} \mathrm{~A}$ firm intention announcement must be made when a mandatory offer is required or when an offeror has transmitted a firm intention to make an offer and is ready, able and willing to proceed with the offer. ${ }^{102}$ It must be emphasised that only when the procedures are adhered to could a firm intention announcement be made. This would involve the offeror approaching the board with sufficient merit to implement the offer in full, ${ }^{103}$ in addition to convincing the independent board that the offer will be fulfilled. ${ }^{104}$ All material facts concerning price-sensitive information must be kept confidential before a firm intention announcement. ${ }^{105}$ When a firm intention announcement has been implemented, the offeror must proceed with the offer; in consequence, the offer cannot be withdrawn without the consent of the offerees. ${ }^{106}$ Where the offeror breaches its obligation to the offerees after the implementation of the firm intention

95. Section 3.9 of the JSE Listings Requirements.

96. Section 11.40 of the JSE Listings Requirements.

97. Rule 94(2) of the Companies Regulation 2011.

98. Rule 95(2) of the Companies Regulation 2011

99. Rule 95(7) and (8) of the Companies Regulation 2011.

100. For the test to determine whether a party has acted negligently, see Lomagundi Sheetmetal \& Engineering (Pty) Ltd v. Basson 1973 (4) SA 523 (RA) and Gordon v. Da Mata 1969 (3) SA 285 (A). Of course, wrongfulness an element which is best expressed in the theory of legal conviction of the community, will have to be established as well, see Schultz v. Butt 1986 (3) SA 667 (A) 679; SM Goldstein \& Co (Pty) Ltd v. Cathkin Park Hotel (Pty) Ltd 2000 (4) SA 1019 (SCA) 1024 and Minister van Polisie v. Ewels 1975 (3) 590(A), at 596H-597G.

101. See P. Nkoane, 'How are offers for Minority Securities Enforced in Corporate law?', 3(2) Journal of Corporate and Commercial Law \& Practice 52, at 66-8 (2017).

102. Rule 101(1) of the Companies Regulation 2011.

103. Rule 99(1), (3) and (4) of the Companies Regulation 2011.

104. Rule 95(4) of the Companies Regulation 2011.

105. Rule 95(2) of the Companies Regulation 2011.

106. Rule 101(1) of the Companies Regulation 2011. 
announcement, offerees could find remedies either in delict or contract law. ${ }^{107}$

A solicitation campaign may ensue any time after a firm intention announcement. ${ }^{108}$ The function of the solicitation campaign is basically to, first, communicate the terms of an offer to the relevant security holders; second, determine which of the security holders accepts the offer; and finally, conduct a ballot in respect of the offer. In cases where specific security holders have been approached by the offeror, and the offeror has tendered to acquire their securities, a solicitation campaign would be directed at minorities who seek to depart the company. In this instance, the solicitation campaign may be conducted before or after the initial acquisition. ${ }^{109}$ Once the solicitation campaign is completed and the offer is accepted, a full contract between the offeror and the offerees comes to life. It is quite overt that the firm intention announcement protocol has aided the task of determining when the offeror should bear the obligation to undertake its takeover vows.

\section{The Effect of the Firm Intention Announcement and the Leverage of Minority Shareholders}

In this section, the author sets out to canvass cases of breach of takeover rules in the context of mandatory offers. It is possible that the offeror or the offeree, or even both, could be held responsible for failed acquisitions. It must be understood that a firm intention announcement precedes the solicitation campaign. After a firm intention announcement is published, the offeror bears the obligation for reparation where its deportment is in breach of the takeover rules - where the offer would have been accepted. This kind of infractions are discussed first. However, it is similarly possible that the offeree could reject the offer or fail to counter-perform timely, resulting in a breach of contract and subsequent rescission of the contract. In this instance, the question is, will minorities have recourse if they have accepted the offer and are willing to offer counter-performance? The author intends to analyse these infractions and to provide an opinion on the merit of the argument that none of the parties bear any responsibility towards minorities.

107. See note 10 and 100 above. Also see D. Hutchison and C.J. Pretorius (eds.), The Law of Contract in South Africa, 2nd ed. Oxford and Cape Town (2012), at 133: 'if the breach occurs due false statements been made, the innocent party will surely sue in contract, and if it was made fraudulently or even negligently, he or she is most likely to sue in delict, since he or she will then be able to recover consequential losses as well'.

108. Rule 93 of the Companies Regulation 2011.

109. Subsection 123(3) and (4) of the Companies Act 71 of 2008
6.1 Where the Offeror Breaches the Takeover Rules

The offeror could surely fail to perform all its takeover undertakings. There are two kinds of takeover infractions that must be separated in respect of takeover rules. First, the author discusses situations where the offeror fails to acquire all the offerees' securities, and second, situations where the offeror fails to acquire minority securities only.

In situations where the offeror withdraws from the negotiations before a firm intention announcement is made, no offeree attains legal standing to sue, except in the clearest of cases. This could be the case where the offeror has concluded a contract with the offeree before an attempt to make a firm intention announcement. In any event, this sort of indenture may be voidable because it may amount to a major breach of the takeover rules. ${ }^{110}$ If the offeror has proceeded with negotiations to a point where a firm intention announcement is made, thereupon the offeror undertakes legal liability. The making of a firm intention announcement concomitantly creates a quasi- or phantom contract between the offeror and would-be offerees. This formation is referred to as a quasi- or phantom contract because before the offerees accept the offer, the only person who is bound by the contract is the offeror, and the offeror cannot rescind the contract without assuming a legal burden. ${ }^{111}$

Where the offeror fails to honour the takeover rules after the making of a firm intention announcement, the offeror assumes the responsibility to repair the damage that is caused by its breach. The Panel, in terms of the companies' regulations, is granted the power to exercise bank guarantees made during the offer to satisfy the purchase. ${ }^{112}$ Equally, it is possible that the Panel may be unable to access the funds to satisfy the offeror's performance. It must be marked that the regulations empower the Panel to act on behalf of security holders when the offeror neglects to pay and not when the offeror refuses to pay and intends to rescind the agreement. It must be kept in mind that the mandate rule in banking law protects the account holder against unauthorised transactions. Thus, when the account holder has intimated to the bank that certain transaction should not or should be executed, the bank should submit to the request. ${ }^{113}$ In cases of refusal to continue with the offer, judicial intervention should be pursued. The high court has jurisdiction to grant relief in such cases.

In an effort to enforce compliance with the takeover rules, the court can order the offeror to acquire the targeted securities in addition to minority securities. ${ }^{114}$ The court can sanction an order of specific performance. ${ }^{115}$ However, the court is not constrained to sanc-

110. Section 127 of the Companies Act 71 of 2008

111. See Nkoane (2017), above n. 101, at 68.

112. Rule 111(4) and (5) of the Companies Regulation 2011.

113. Nedbank v. Pestana 2009 (2) SA 189 (SCA)

114. Benson v. SA Mutual Life Assurance Society 1986 (1) SA 776 (A).

115. See Badenhorst v. Theophanous 1988 (1) SA 793 (C); Oliver v. Stoop (1978) 1 SA 196 (T); Carpet Contractors (Pty) Ltd v. Grobler 1975 (2) 
tion an order of specific performance - the granting is subject to judicial discretion. ${ }^{116}$ Where the court declines to grant an order of specific performance or where the holders of the targeted securities ${ }^{117}$ have elected to seek damages, the right extended to minorities to seek an order of specific performance automatically expires. This is so because minorities would no longer be exposed to the peril that comes with the alteration of the company's control. ${ }^{118}$ Therefore, minorities should embark on the route that leads to the destination of contractual damages. This means that the offeror would only be liable to pay for damages flowing from its breach of contract. ${ }^{119}$ In consequence, minorities cannot demand an order of specific performance as framed by Cameron $\mathrm{J}$ in Sefalana. ${ }^{120}$ It is doubtful whether it is historically, economically and, therefore, legally acceptable to approve Cameron's construction. It would be legally and commercially problematic to insist that the offeror who failed to attain control of a target company should subsequently be forced to be a minority security holder of the same. This, in my estimation, does not symbolise fair and equal treatment of all affected security holders.

The scenario changes quite dramatically where the court has enforced specific performance for acquisition of the targeted securities. In this situation, two legal remedies become available to minorities: specific performance and damages. It is entirely in the discretion of the minorities which remedy they may invoke.

Where the offeror has completed a purchase of the targeted securities, minorities by design gain the right to specific performance. If the offeror has failed to extend an offer to minorities, by virtue of implementing a firm intention announcement the offeror would have assented to an agreement with the minorities that entitles them to an order of specific performance. This is so because of the change of control in the offeree company. ${ }^{121}$ Where control of the company has changed, it is accurate to argue that minorities should receive the same treatment as the outgoing shareholders. The minorities should be shielded from the abuse corporate bullies or company looters may inflict on them during or after takeovers. ${ }^{122}$ Where specific performance is

SA 436 (T); Farmers' Co-op Society (Reg) v. Berry 1912 AD 343 and Ex Parte Neethling 1951 (4) SA 331 (AD).

116. Benson v. Mutual Life Assurance Society 1986 (1) SA 776 (A), at 782-3 and Ex Parte Neethling 1951 (4) SA 331 (AD), at 335.

117. By the term targeted securities, the author implies securities that the offeror initially sought, this excludes minority securities

118. Sefalana Employee Benefits Organisation v. Haslam 2000 (2) SA 415 (SCA), Para. 7.

119. S. Van der Merwe et al., Contract General Principles, 4th ed., Cape Town: Juta (2012), at 357.

120. See Haslam v. Sefalana Employee Benefits Organisation [1997] 4 All SA 269 (W), at 276-9.

121. Sefalana Employee Benefits Organisation v. Haslam 2000 (2) SA 415 (SCA), Para. 4. 'It is only when the stage is reached at which an intended or proposed transaction will, if consummated, result in a change of control within the meaning of the Code that the hand of the panel is laid upon the transaction'

122. See Spinnaker Investments (Pty) Ltd v. Tongaat Group Ltd 1982 (1) SA $65(A)$, at 71. sought for the enforcement of the agreement, as previously averred, the granting of that order will depend on the discretion of the court. ${ }^{123}$ In light of what the takeover machinery is aimed to achieve, the court intending to secure minority protection may grant the order of specific performance, unless the order creates an injustice. ${ }^{124}$ Even so, the minorities are afforded the liberty to select the redress in the form of specific performance or the suit of damages. Where it is clear that the granting of an order of specific performance may result in the offeror suffering financial hardship and cannot be reconciled with the circumstances at hand, and that the transaction will not put minorities at risk, the court may award damages instead of specific performance. ${ }^{125}$ Even though, the change of control may have occurred, the transformation of the company must not result in the mistreatment of minorities. Where the mistreatment of minorities is improbable, the court may award damages in lieu of an order of specific performance. This leads to the question of whether minorities will receive equal treatment as their securities will not be acquired.

\subsection{Where the Offeree Breaches Contract Law Rules or Rejects the Offer}

The situation where the offerees reject or breach the agreement for acquisition of their securities poses obvious difficulties. A firm intention announcement creates a phantom or quasi-contract binding the offeror alone. Thus, the offeror attains no standing to sue where its offer is rejected. Only when its offer is accepted, firmly bringing a contract into existence, and later repudiated, the offeror will have locus standi. The author elucidates this situation in a contract law matrix.

The solicitation campaign facilitates the purpose of transmitting an offer to the offerees, and only when the offerees accept the offer will a full contract be constituted. ${ }^{126}$ The offer on its own does not perfect a contract only acceptance of a valid offer does. ${ }^{127}$ Thus, the offer lapses or perishes if it is rejected. This means that if the offeree makes a counteroffer, the offeree rejects the offer. The rejection of the offer releases the offeror from the obligation created by the firm intention announcement. The question then is, if minorities would have assented to a contract which the majority offeree rejected or repudiated, or both the offeror and the majority offeree mutually agreed to terminate, will minorities be afforded recourse?

It has become clearer by now that a firm intention announcement creates a legal promise to the offerees (i.e. majority offeree and minority offeree). The emer-

123. Benson v. Mutual Life Assurance Society 1986 (1) SA 776 (A), at 782-3; Ex Parte Neethling 1951 (4) SA 331 (AD), at 335 and Carpet Contractors (Pty) Ltd v. Grobler 1975 (2) SA 436 (T), at 441.

124. Benson v. Mutual Life Assurance Society 1986 (1) SA 776 (A), at 782-3.

125. Farmers Co-operative Society (Reg) v. Berry 1912 AD 319, at 324 and Ras v. Simpson 1904 TS 254, at 256.

126. Bird v. Sumerville 1961 (3) SA 194 (A); McKenzie v. Farmers Cooperative Meat Industries Ltd 1922 AD 16 and Godfrey v. Paruk 1965 (2) SA 738 (D).

127. Efroiken v. Simon 1921 CPD 367. 
gence of this agreement gives one the impression that minorities would have recourse if the phantom or perfected agreement is breached by the principal offerees, but the author believes otherwise.

The offer must be unconditionally accepted before a binding agreement is created; a conditional acceptance amounts to a counteroffer. ${ }^{128}$ The offeror would often approach the offeree company with the ambition of acquiring a certain number of securities, in addition to those imposed by statutory law, that is, mandatory offers, and would make an offer to that effect. The majority acceptance of the offer will constitute a full contract, as mandatory offer is an auxiliary or a secondary offer. Where only minorities accept the offer and the majority offerees reject it, the acceptance becomes conditional and equivocal, and no valid contract comes to life. ${ }^{129}$ This is because an offer must be accepted in full and at the terms set out in the offer. ${ }^{130}$ Similarly, when the majority offerees repudiate the contract, the supervening impossibility to carry out the agreement arises for minorities. ${ }^{131}$ This in actual fact makes the contract between the offeror and the minorities impossible. Consequently, do minorities have any recourse?

It could perhaps be submitted that minorities could seek redress by suing the majority for damages, if the majorities were responsible for the cancellation of the agreement. ${ }^{132}$ Nevertheless, it is explicit that minorities cannot seek reparation from the majority holders. This is because there is no indenture, whether actual or ostensive, between the minorities and the majority. In truth, a firm intention announcement creates a bond, binding only the offeror to fulfil a promise to the offerees, and not between the offerees themselves. By the same token, it could be argued that owing to the bond created between the offeror and offerees, minorities could aver that, as the offeror was aware of the fact that the solicitation campaign does not guarantee acceptance of the offer by all securities holders, it stands to reason that those who accept the offer should be afforded recourse. This sort of argument would prove futile, as minorities will simply be resisted with the exceptio nonadempleticontractus $^{133}$ if they invoke an order of specific performance. ${ }^{134} \mathrm{~A}$ defence of the exceptio should be based on the

128. Boerne v. Harris 1949 (1) SA 793 (A)

129. Van Jaarsveld v. Ackerman 1975 (2) SA 753 (A). also see rule 81(d) of the Companies Regulations of 2011.

130. Laws v. Rutherford 1924 AD 261.

131. Kudu Granite Operations (Pty) Ltd v. Caterna Ltd 2003 (5) SA 193 (SCA) and Peters Flamman \& Co v. Kokstad Municipality 1919 (AD) 427.

132. The lawsuit could occur because a repudiation of the contract could deny minorities to claim the premium offered for their securities or the price of their securities depreciates due to the termination of the contract.

133. The exceptio non adempleti contractus as a defence is restricted to reciprocal contracts where both parties are to perform simultaneously or where it is required that one party performs before the other. Thus, where a party fails to perform satisfactorily, the defendant can ward off a claim with this principle.

134. Grand Mines (Pty) Ltd v. Giddey NO [1998] JOL 4146 (A); Kamaludin v. Gihwala 1956 (2) SA 323 (C) and BK Tooling (Edms) Bpk v. Scope Precision Engineering (Edms) Bpk 1979 (1) SA 391 (A). terms of the purported agreement, that is, since the offeror contracted to acquire a certain number of securities, for the offeree to enforce the contract, the offeree must first render full performance (i.e. the minorities must deliver the amount of securities the offeror tendered to purchase in its offer). This, in fact, would amount to an impossibility that renders the purported contract between the minorities and the offeror void. ${ }^{135}$ Where the majority offeree rejects the offer or repudiates the contract, minorities will not have a right to legal recourse. This sort of consequence, in my opinion, does not support the theory of equal treatment during acquisitions.

In cases where the offeror and the majority offerees have mutually agreed to terminate the concluded agreement, minorities may have a legitimate case for damages against the offeror, since the offeror would have been mindful that its action might disenfranchise the minorities. ${ }^{136}$ That said, the measure of liability would very much hinge on other factors, ${ }^{137}$ for instance, if undue hardship has compelled mutual cancellation, then the prospect of the court awarding damages to the minorities becomes slim.

\section{The Technique to Balance the Equities and Remedies to Liberate the Situation}

The takeover rules are intended to protect security holders; even so, there is no guarantee that minorities may receive equal treatment. The question, thus, arises whether mandatory offers merely make takeovers expensive without guaranteeing equal treatment for all security holders. ${ }^{138}$ This is so because the firm intention announcement precedes the solicitation campaign ${ }^{139}$ the offeror will then have to approach the offeree company with the ambition to acquire all its voting share stock. The mere fact that a party makes an offer that culminates in an affected transaction means that the party must be able and willing to implement mandatory

135. Wilson v. Smith 1956 (1) SA 393 (W).

136. For instance, the offeror and majority offerees may reach a compromise which extinguishes a contract.

137. Administrator, Natal v. Edouard 1990 (3) SA 581 (A) 597. In an obiter dictum, the court ventured into the issue of fault and contractual damages. The court averred that fault is not a central factor in whether damages ought to be awarded where the contract is terminated. However, it must be argued that where fault created the resultant damage, the guilty party must bear the obligation for reparation similar to what would happen in cases of delict. The court would then have to determine whether the breach has resulted in a contractual damage or a delictual damage. If it is found that the damage could be established on delict, thereupon the court must measure the degree of damages suffered.

138. M.P. Larkin and J. Boltar, 'Company Law (Including Close-Corporation)', Annual Survey of South African Law 403, at 431 (1997) and J.R. Wiblin 'Mandatory Takeover Offer - Too High a Price for the Economy to Pay?', 29(3) Journal for Juridical Science 173-85 (2004).

139. See Section 5.2 
offers. ${ }^{140}$ It is submitted that 'no person may enter into an affected transaction unless that person is ready, able and willing to implement that transaction'; moreover, 'no person must make an offer unless that person is ready, able and willing to proceed with the offer'. ${ }^{141}$ As illustrated earlier, offerors may not even make offers or fulfil offers for minorities' securities - the Sefalana case affirms this truth. ${ }^{142}$ Minorities may believe that their securities will be bought when a firm intention announcement is made, but it has been made clear that minorities may not receive equal treatment where the court cannot compel the offeror to acquire minority securities.

To moderate the aforementioned problems, the procedures of takeovers should be altered. It is fair to argue that a party should affirm its intention to acquire securities only when the party is aware of the number of security holders who are willing to sell. This implies that a party should only make a firm intention announcement when the party knows the degree of liability involved. It is, therefore, suggested that the solicitation campaign should precede a firm intention announcement. The offerees ought to be informed that a solicitation campaign does not inevitably mean that an offeror will be compelled to proceed with an offer. This is because, if those who accept the offer are a few, then their acceptance will amount to a counteroffer, which may be accepted or rejected.

It is rather difficult to understand why the firm intention announcement should succeed the solicitation campaign. The offerees could either accept the offer or reject it when approached. Perhaps the rationale is that, to secure market credibility and stability, security holders should only be approached when the offeror is able and willing. ${ }^{143}$ But whether the offeror is able and willing to fulfil the offer is a matter that has to be determined during negotiations. ${ }^{144}$ Similarly, an enquiry into which offeree is willing to sell should not be interpreted as meaning that an obvious sale is in the offing.

In appropriate cases, companies should annually collect data indicating which of the minority security holders will sell if an offer triggers a mandatory offer. Thus,

140. P. Delport et al., Henochsberg on the Companies Act 71 of 2008 (2014), at 431-3.

141. Section 119 (2)(a) of the Companies Act 71 of 2008 and rule 101 of the Companies Regulations 2011.

142. Haslam v. Sefalana Employee Benefits Organisation [1997] 4 All SA 269 (W).

143. It could be argued that the securities price could be easily manipulated or fluctuate through the making of offers before the firm intention announcement, which would push the price of securities up. Market dynamism dictates that when supply exceeds demand, the price of the commodity would drop, and when demand exceeds supply, the price would rise. However, before the solicitation campaign is conducted, the information must be kept confidential. Thus, the solicitation campaign would involve the market price of securities at that juncture. The making of a cautionary announcement should guarantee that sensitive information is kept confidential. This should keep the prices stable, and the matter of the payment of premiums on the purchase price should be a matter between the offeror and offerees. It is trite that any pricesensitive information should remain confidential throughout the period of acquisition. This should benefit the offeror and the offerees.

144. Rule 99(1) and (3) of the Companies Regulation 2011. when a majority shareholder is approached for the acquisition of its securities, the number of minorities who intend to sell is readily available. The company, in collecting this data, must point out to the security holders that only those who have specified the need to sell will be given first preference when offers are made. ${ }^{145}$ Thus, minorities can exercise their right to sell prior to bids, and upon submissions of bids, the minority shareholders have an option to sell or not to sell. This information will be important in communicating adequate information to the offeror, specifying the merit of the offer and the purchase price, including the mandatory offer price. Therefore, a firm intention announcement should be made based on that information. When offers include minority securities, equal treatment of all security holders is automatically guaranteed.

\section{Conclusion}

In many takeover regimes around the world, the issue of equal treatment may be regarded as important; nevertheless, a proper analysis may expose gaps in the equal treatment theory. Takeover regimes in the Netherlands and the United Kingdom seem to be focused on the main offer; however, there is no doubt that the regimes contain mandatory offer rules to promote protection for minorities. Whether the regimes are fully entrenched with rules that compel equal treatment of all shareholders in all cases leaves much doubt. In some cases, the minorities must approach the court before they can enjoy the same treatment as the majority, and surely the minorities may fail to enforce equal treatment. The British and the Dutch systems, compared with the South African system, appear to marginalise minorities; in the latter system much was done to promote equal treatment, but that much seems not to be enough. Equality, like justice, is time sensitive: equality delayed is equality denied.

The disparity in the courts' decisions in takeover matters has led South African lawmakers to revise takeover procedures. The enactment of the firm intention announcement rule has moderated the initial glaring leak in the takeover boat and provides direct remedies to minorities in takeovers. This article has demonstrated that a firm intention announcement, to some extent, warrants equal and fair treatment of affected security holders. When a firm intention announcement is made, the offeror is compelled to fulfil its takeover vows. This clearly affirms the principle of equal treatment in takeovers. Even so, the article has illustrated that the leak is not completely sealed. The principle of equal treatment in some cases is a mere fallacy, and the procedures currently adopted represent a deterrence rather than a measure of protection for minorities. It has been argued elsewhere that clearer and stricter takeover rules benefit

145. Some shareholder regard their shareholding as a long-term investment and may not be enticed to sell any time sooner. 
security holders, particularly minority security holders. $^{146}$

With the proposed amendments, the rules will be clearer, and the cost of acquisition could be ascertained after the solicitation campaign. It could be argued that this could present an opportunity for looters. The author believes that should not be the case. It is the duty of the board to probe the merit of the offer, in tandem examining the intentions of the offeror, before conducting a solicitation campaign. And, if the need arises, the information gathered should be filed in the company's memorandum of association, where it may be invoked if the offeror intends to act contrary to its prior assertions. Moreover, the fundamental transactions rules should prove enough in derailing possible looters. ${ }^{147}$ 